
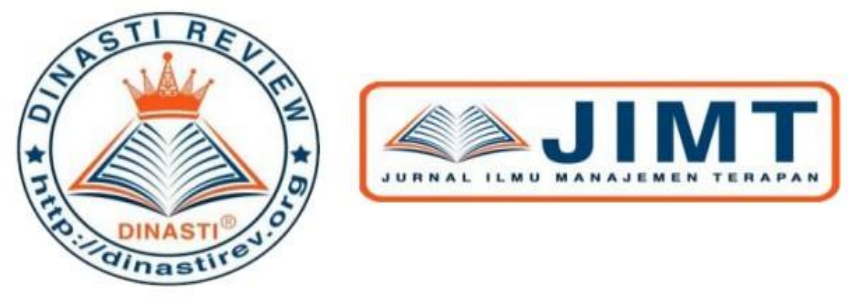

\title{
STRATEGIC MANAGEMENT ANALISIS SWOT PADA PRODUK CAKEKINIAN
}

\section{Khairun Nisa}

Universitas Mercu Buana, Jakarta, Indonesia

\begin{tabular}{|c|c|}
\hline $\begin{array}{l}\text { ARTICLE INFORMATION } \\
\text { Received: } 22 \text { April } 2020 \\
\text { Revised: } 2 \text { Mei } 2020 \\
\text { Issued: } 10 \text { Mei } 2020 \\
\text { Corresponding author: } \\
\text { Khairun Nisa }\end{array}$ & $\begin{array}{l}\text { Abstrak: Cakekinian sesuai dengan namanya adalah } \\
\text { produk kue bolu yang mengikuti tren masa kini. Bisnis } \\
\text { kuliner yang dijalankan oleh pasangan selebgram } \\
\text { Arief Muhammad dan Tiara Pangestika seorang } \\
\text { enterprenuer muda dan juga youtuber. Memiliki daya } \\
\text { saing yang cukup kuat karena memiliki produk dan } \\
\text { brand image yang unik didukung dengan kualitas juga } \\
\text { citarasa yang selalu memberi kepuasan pada } \\
\text { konsumennya. Tujuan adanya penelitian ini salah } \\
\text { satunya yaitu untuk mempelajari kondisi dari segi } \\
\text { kekuatan dan kelemaham juga peluang dan ancaman } \\
\text { yang ada pada bisnis Cakekinian melalui Analisis } \\
\text { SWOT. Dengan menggunakan metode penelitian } \\
\text { deskriptif dan dengan pengumpulan data sekunder } \\
\text { dapat disimpulkan bahwa kekuatan yang dimiliki } \\
\text { lebih besar dari kelemahan yang ada serta peluang } \\
\text { yang ada juga memiliki skor lebih tinggi dibandingkan } \\
\text { dengan nilai skor ancaman melalui faktor internal } \\
\text { maupun eksternal. Untuk itu perusahaan dapat } \\
\text { memanfaatkan beberapa strategi seperti mulai } \\
\text { menggunakan sistem online agar mempermudah } \\
\text { konsumen dalam mendapatkan produk yang } \\
\text { diinginkan, menambah outlet dan selalu menambah } \\
\text { inovasi agar dapat mempertahankan dan } \\
\text { mengembangkan Cakekinian secara mendunia. } \\
\text { Kata Kunci: Analisis SWOT, Cakekinian, Strategi. }\end{array}$ \\
\hline
\end{tabular}

\section{PENDAHULUAN}

Pesatnya perkembangan teknologi informasi dan komunikasi seperti media massa, menyebabkan terjadinya perubahan secara cepat dimana-mana. Perubahan tersebut telah membawa sedikit demi sedikit membawa masuk masyarakat kesuatu pola budaya yang baru dan mulai menentukkan pola pikir serta budaya perilaku remaja. Pada umumnya, remaja yang mengikuti perkembangan ini dipengaruhi oleh faktor eksternal yaitu teman sebayanya. Yang terkena dampak dari media massa ini antara lain gaya hidup yang pastinya akan terus berubah seiring dengan perkembangan media massa, karena semakin banyaknya kebutuhan hidup manusia, semakin menuntut pula terjadinya peningkatan gaya hidup (lifestyle). 
Gaya hidup ini, bukan hanya berupa fashion atau semacamnya. Tetapi, trend makanan juga ikut berpengaruh dengan berlanjutnya gaya hidup konsumtif para remaja saat ini. makanan atau pangan yang menjadi salah satu kebutuhan primer masyarakat. Kebutuhan primer merupakan kebutuhan dasar manusia yang harus dipenuhi. Urutan absolutnya adalah Sandang, Pangan, Papan. Yang filosofinya Pangan (makanan) bermakna keharusan berusaha mewujudkan mimpi agar menjadi nyata. Karena merupakan sumber yang paling penting dalam kehidupan manusia, maka banyak bermunculan inovasi di bidang makanan ini, tidak terkecuali kue kekinian yang sedang banyak di perbincangkan masyarakat saat ini.

Penelitian ini dilakukan pada perusahaan yang fokus memproduksi cake unik yang dimiliki oleh seorang youtuber yaitu Arief Muhammad. Produk dari perusahaan tersebut telah dikenal oleh banyak customer dengan berbagai macam kriteria. Perusahaan ini berusaha menciptakan produk yang dapat disukai oleh semua kalangan masyarakat dan dapat disesuaikan dengan kemampuan konsumen untuk dapat membeli produk tersebut, untuk dapat memperkenalkan produk dari perusahaan tersebut, maka perusahaan harus memiliki cara kreatif dalam beriklan agar dapat menarik perhatian konsumen dan menciptakan preferensi terhadap merek. Banyak masyarakat di Indonesia yang ingin membeli kue kekinian tersebut bukan karena kebutuhan atau cita rasa dari kue tersebut, akan tetapi hanya ingin mengikuti trend yang sedang berkembang di masyarakat.

Cakekinian sesuai dengan namanya adalah produk kue bolu yang mengikuti tren masa kini. Bisnis kuliner yang dijalankan oleh pasangan selebgram Arief Muhammad dan Tiara Pangestika seorang enterprenuer muda dan juga youtuber yang beralamat di Jl. Bintaro Utama I Blok F2 No. 6, Bintaro Pesanggrahan, Jakarta Selatan. Cakekinian launching pertama kali di cafe Foresthree pada tanggal 9 September 2017 yang berlokasi di kota Bogor, saat ini Cakekinian juga telah memiliki beberapa Outlet di berbagai kota besar seperti kota Tangerang Selatan, Bekasi, Surabaya, Bandung, DIY, dan Jakarta, untuk jenis produk yang ditawarkan beragam varian rasa, seperti : Oleo Red Velvet, Kitcake Matcha, Bang-Bang Chocolate, Helshey Cookies n Cream, Triple Choco Oleo, Galaxy, Ufomaltine, Milov, Nastar Cheese Cake, Helseys Cookies and Cream, Kopi cake. Awalnya yang menjadi pelopor bisnis kue kekinian adalah bisnis oleh-oleh kue daerah yang diawali dengan berdirinya sebuah outlet kue milik Dude Harlino dengan Jogja Scrummy dan Teuku Wisnu dengan Malang strudelnya. Lalu hadirlah outlet kue milik Irwansyah yang dinamai Palembang Lamonde dan Medan Napoleon. Melihat antusias yang besar dari masyarakat dengan hadirnya outletkue ini, maka Irwansyah bersama beberapa artis membuat management Jannah Corporation (J.Corp) dengan menggunakan nama owner artis masing-masing yang sudah mempunyai ketenaran yang besar maka dengan cepat kue kekinian ini cepat digemari oleh masyarakat.

Dalam kurun waktu beberapa tahun kebalakang bisnis kue memiliki potensi besar dan mulai di lirik oleh kalangan para artis Indonesia yang mulai terjun kedunia bisnis usaha kue. Seiring berkembangnya bisnis kue di kalangan artis tanah air, mengakibatkan persaingan yang semakin ketat. Mengutip berita (Kompasiana, 2018) menjamurnya kue artis di Indonesia juga diikuti dengan tingginya kontribusi kuliner terhadap Produk Domestik Bruto Ekonomi Kreatif Indonesia yang sebesar 41,69\%. Salah satu faktor kontribusi kuliner yang besar selain dikarenakan oleh kebutuhan dasar masyarakat Indonesia, namun juga karena meningkatnya inovasi-inovasi di dunia kuliner yang salah satunya adalah kue brand dari artis-artis tersebut. Berdasarkan data dari Gabungan Pengusaha Makanan Minuman (GAPMMI), mengatakan bahwa roti telah menepati urutan ketiga setelah nasi dan mie sebagai makanan pokok masyarakat Indonesia. Mengutip data Euromonitor, pertumbuhan rata-rata periode (CAGR) 2010-2014, bisnis roti dan kue Indonesia naik 14\%. Sedangkan proyeksi pertumbuhan CAGR periode 2014-2020 untuk bisnis roti dan kue 10\%. Sampai 2020, targetnya potensi bisnis roti dan kue nilainya mencapai Rp 20,5 triliun. Ini membuktikan perkembangan dunia bisnis roti dan kue setiap tahunnya mengalami peningkatan. (www.kontan.co.id). 
Begitu fenomena sosial berupa kue kekinian yang dimiliki oleh para artis ini muncul, tidak terlepas dari pengaruh media sosial yang berkembang saat ini salah satunyainstagram. Instagram bukan hanya menjadi tempat untuk berinteraksi, berbagi foto dan video saja, tetapi juga menjadi wadah untuk menunjukkan eksistensi diri dengan mengikuti trend yang berkembang di masyarakat pada saat ini. Di dalam Instagram, pengguna sebagai aktor memainkan peran yang sesuai dengan kesan yang ia harapkan. Termasuk dalam pengambilan gambar yang baik maka ia harus mengedit fotonya dengan semaksimal mungkin. Banyak orang yang membagikan momen-momen kegiatan pribadinya setiap hari sepertijalan-jalan, nongkrong di kafe, makan di restoran, dan kegiatan konsumtif lainnya di media sosial instagram yang kemudian menjadi konsumsi publik. Akan tetapi, perilaku tersebut ternyata hanya untuk menunjukkan eksistensi diri mereka kepada masyarakat lain ataupun teman-teman media sosialnya.

Cakekinian adalah perusahaan kue bolu yang dimiliki oleh Arief Muhammad seorang enterprenuer muda dan juga youtuber. Cakekinian ini launching pertama kali di restoran Foresthree pada tanggal 9 September 2017, untuk jenis produk yang ditawarkan beragam varian rasa, seperti: Oleo Red Velvet, Kitcake Matcha, Bang-Bang Chocolate, Helshey Cookies $n$ Cream, Triple Choco Oleo, Galaxy, Ufomaltine, semua varian rasa dijual dengan harga Rp 58.000. Mengutip berita dari (Kompas.com, 2017) dalam waktu kurang lebih selama enam hari gerai dibuka, kue dengan beragam varian rasa laris terjual. Saat grand launching antrian pembeli cukup banyak dan pada hari itu juga habis terjual sebanyak 3.500 box cake, selama enam hari selalu menjual kue hingga persediaan habis. Gerai kue tersebut diperkirakan sudah menjual 12.000 hingga 13.000 box kue dalam waktu enam hari. Jika dirata-rata, per harinya terjual 1.500 hingga 2.000 box kue.

Inovasi yang berkembang di bidang kuliner ini dimanfaatkan oleh para pesohor tanah air untuk membuka usaha di bidang kuliner di kota Bogor yakni dengan membuka toko kue kekinian. Setidaknya ada empat outlet kue kekinian yang ada di kota Bogor antara lain rain cake kepunyaan dari Shireen Sungkar, cake ala ali yang dimiliki oleh pesinetron Ali Syakieb, ada juga princess cake yang dimiliki oleh penyanyi Syahrini, dan juga outlet Cakekinian yang dimiliki oleh youtubers sekaligus penulis buku Arief Muhammad beserta sang istri. Karena outlet kue kekinian yang ada di kota Bogor rata-rata dimiliki oleh artis ibukota, maka trend kue kekinian di kota Bogor dengan cepat menyebar ke masyarakat. Hal tersebut dapat dijadikan sebagai salah satu strategi pemasaran. Didalam memasarkan suatu produk baru tentu terkadang tidak begitu terpandang oleh masyarakat, namun dengan terkenalnya pemilik brand tersebut tentu akan mempermudah dikenalnya brand produk tersebut.

Menurut Kotler (2012) strategi bersaing adalah strategi yang secara kuat menempatkan perusahaan terhadap pesaing dan yang memberi perusahaan bersaing yang sekuat mungkin. Kemampuan suatu perusahaan untuk bersaing sangat ditentukan oleh kinerja perusahaan itu sendiri. Selain dengan memanfaatkan ketenaran owner, Cakekinian juga dapat memanfaatkan teknik pop-up yang merupakan iklan yang sering muncul ketika seseorang membukan website tertentu, memaksimalkan fitur hashtag "\#” di instagram Cakekinan dengan cara setiap posting dalam instagram Arief Muhamad menyelipkan produk Cakekinian dalam kehidupan sehariharinya, memberikan promo bucket agar konsumen memiliki kesempatan untuk merasakan semua varian rasa sekali beli. Komunikasi dapat digunakan dalam berbagai konteks, salah satunya adalah komunikasi massa, dimana media yang digunakan adalah media massa yang sudah terlembaga dengan komunikan adalah masyarakat luas.

Konteks komunikasi massa sering digunakan dalam berbagai macam kegiatan, seperti politik, ekonomi, dan lain sebagainya tergantung tujuan komunikator pada target penerima informasi yang dituju. Selain dari produknya kepada masyarakat luas, salah satunya adalah produk Cakekinian, yaitu produk kuliner yang melakukan komunikasi pemasaran dengan tujuan untuk membujuk khalayak membeli produknya. Pada konteks Cakekinian dapat diasumsikan bahwa tindakan promosi yang dilakukan oleh perusahaan merupakan stimuli yang 
diberikan kepada konsumen sebagai organisme yang akan memberikan respon terhadap stimuli tersebut. Dalam hal ini respon yang diberikan adalah keputusan pembelian terhadap produk yang dipromosikan. Cakekinian yang memposisikan sebagai "kue kekinian" dengan konsep "kue youtuber" telah menjadi suatu fenomena baru di tengah dari maraknya "kue kekinian" dengan konsep "kue artis".

\section{KAJIAN PUSTAKA}

Menurut Kotler \& Keller (2009), mendifinisikan manajemen pemasaran sebagai seni dan ilmu memilih pasar sasaran dan meraih, mempertahankan, serta menumbuhkan pelanggan dengan menciptakan, menghantarkan dan mengkomunikasikan nilai pelanggan yang unggul. Menurut Assauri (2013) Manajemen pemasaran adalah kegiatan menganalisis, merencanakan, melaksanakan dan mengendalikan program-program yang disusun dalam pembentukan, pembangunan, dan pemeliharaan keuntungan dari pertukaran atau transaksi melalui sasaran pasar dengan harapan untuk mencapai tujuan organisasi (perusahaan) dalam jangka panjang. Sedangkan manajemen pemasaran menurut Alma (2010) adalah proses perencanaan dan pelaksanaan konsepsi, penetapan harga, promosi dan distribusi gagasan, barang, dan jasa, untuk menghasilkan pertukaran yang memuaskan individu dan memenuhi tujuan organisasi.

Berdasarkan definisi diatas dapat disimpulkan bahwa manajemen pemasaran merupakan kegiatan suatu ilmu dan seni dalam melaksanakan atau merencanakan suatu konsep untuk menciptakan juga mengkomunikasikan serta menumbuhkan nilai pelanggan dari transaksi dan atau pertukaran melalui sasaran pasar dengan harapan untuk mencapai tujuan organisasi dalam jangka panjang. Strategi pemasaran adalah pola pikir pemasaran yang akan digunakan untuk mencapai tujuan pemasarannya.

Dalam membuat suatu bisnis tentunya harus memiliki sebuat strategi, karena strategi merupakan salah satu cara atau teknik dalam menjalankan suatu bisnis yang dibuat dan akan berdampak pada jangka pendek ataupun jangka panjang. Strategi dibuat tidak hanya untuk segi pemasaran tetapi juga dari segala segi seperti strategi produk, strategi lokasi dan sebagainya. Strategi pemasaran berisi strategi spesifik untuk pasar sasaran, penetapan posisi, bauran pemasaran dan besarnya pengeluaran pemasaran (Kotler, 2012). Dalam pemasaran terdapat strategi pemasaran yang disebut bauran pemasaran (Marketing Mix) yang memiliki peranan penting dalam mempengaruhi konsumen agar dapat membeli suatu produk atau jasa yang ditawarkan oleh produsen. Elemen-elemen bauran pemasaran terdiri dari semua variabel yang dapat dikontrol perusahaan untuk dapat memuaskan para konsumen.

Menurut Kotler (2012) mengatakan bahwa bauran pemasaran pada produk barang berbeda dengan bauran pemasaran pada produk jasa. Variabel bauran pemasaran pada produk barang terdiri dari empat variabel (4P): produk, harga, tempat atau saluran distribusi, dan promosi. Variabel bauran pemasaran terutama pada produk barang, masing-masing saling mempengaruhi, sehingga semuanya penting sebagai satu kesatuan strategi, yaitu strategi bauran pemasaran. Untuk menentukan semua strategi yang ada tentunya harus dibuat berdasarkan kegiatan dan tujuan dari dibuatnya perusahaan atau bisnis tersebut. Agar strategi yang dibuat dapat memfokuskan ke arah mana bisnis tersebut akan berjalan dan dimana produk yang dibuat akan dipasarkan serta produk yang seperti apakah yang harus dibuat.

Menurut Sallis dalam Yeni, et al (2019) SWOT adalah singkatan dari Stengths, Weaknesses, Oprtunities, dan Threats (kekuatan, kelemahan, peluang dan ancaman). Analisis SWOT sudah menjadi alat yang umum digunakan dalam perencanaan strategi, tetapi tetap merupakan alat yang efektif dalam menempatkan potensi perusahaan. SWOT ini biasa digunakan untuk menganalisis suatu kondisi dimana akan dibuat sebuah rencana untuk melakukan suatu program kerja (Alma, 2008). Analisis SWOT merupakan salah satu intrumen 
analisis yang ampuh apabila digunakan dengan tepat. Telah diketahui pula secara luas SWOT merupakan akronim untuk kata-kata strengths (kekuatan), weaknesses (kelemahan), opportunities (peluang), threats (ancaman) (Siagian, 2012).

Berdasarkan definisi di atas dapat disimpulkan bahwa analisis SWOT adalah singkatan berisi S (Strengths) yang berarti merupakan kekuatan atau ciri khas dan atau keunikan yang dimiliki perusahaan, $\mathrm{W}$ (Weakness) merupakan kelemahan yang harus dihadapi perusahaan dan tentunya harus mencari solusi agar kelemahan tersebut bisa ditutupi dan tidak akan menjadi boomerang bagi perusahaan, O (Opportunities) yang bisa disebutkan sebagai sebuah kesempatan atau bisa juga dikatakan sebagai peluang yang harus dimanfaatkan perusahaan untuk dapat dijadikan salah satu strategi agar dapat membantu mempercepat proses menuju tujuan yang diinginkan, T (Threats) atau bisa disebut juga sebagai salah satu ancaman yang harus diketahui perusahaan seperti pesaing misalnya yang tentunya harus dikenali agar perusahaan dapat bersaing secara baik dan sehat. Hal tersebut yang merupakan cara yang dapat diandalkan perusahaan untuk melakukan analisis suatu kondisi dimana akan dibuat sebuah rencana melakukan pendekatan guna melihat kekuatan, kelemahan, peluan dan ancaman dalam suatu perusahaan.

Menurut Fadli (2019) alat yang digunakan dalam menyusun beberapa faktor strategis perusahaan yaitu merupakan matrik SWOT. Didalam matrik ini dapat dilihat bagaimana perusahaan harus menghadapi peluang juga ancaman secara eksternak sehingga akan menyesusaikan pada kekuatan atau keunggulan dan juga kelemahan yang dimiliki.

\section{METODE PENELITIAN}

Metode yang digunakan pada penelitian ini adalah dengan menggunakan metode deskriptif yang memiliki tujuan secara sistematis membuat deskripsi berdasarkan fakta dan yang akurat. Pada metode deskriptif ini penulis berusaha untuk dapat mengetahui apa saja yang menjadi keunggulan atau kekuatan dan kelemahan, juga peluang serta ancaman berdasarkan data yang diperoleh dan menganalisis serta menginterpretasikannya. Data yang dimiliki dan digunakan pada penelitian ini diperoleh secara sekunder melalui jurnal, buku ataupun website dan sumber lainnya.

\section{HASIL DAN PEMBAHASAN}

Berdasarkan hasil analisis SWOT yang meliputi kekuatan dan kelemahan juga peluang dan juga ancaman pada Cakekinian adalah sebagai berikut:

\section{Faktor Internal}

\section{Strengths (Kekuatan)}

1. Memiliki Brand yang unik

Nama Cakekinian sangat unik dan mudah untuk diingat karena jarang perusahaan atau bisnis kue memberikan nama sedemikian rupa. Jika diartikan lebih mudah lagi disebut sebagai "Kue Kekinian".

2. Bisnis Cakekinian memiliki owner ternama yaitu seorang youtuber dan pengusaha muda Bisnis ini dibuat melalui perkumpulan para selebriti yang bekerjasama untuk membuat perusahaan dalam bidang makanan yaitu kue yang berada di beberapa daerah, khusus Cakekinian dirintis oleh Arief Muhammad dengan nama tenarnya "Poconggg" yaitu salah satu youtubers dan pengusaha muda ternama dikalangan para remaja.

3. Memiliki produk yang unik dan berbeda dari pesaingnya 
Produk Cakekinian merupakan kue bolu yang di mix dengan wafer yang dipadukan dengan cream atau topping tertentu dengan rasa rasa dari cemilan remaja seperti: Beng-Beng, Oreo, Kit Kat, dan sebagainya

4. Memiliki cita rasa yang khas

Rasa-rasa yang dimiliki Cakekinian merupakan rasa yang khas karena didorong dengan nama-nama produknya seperti Milov, ufomaltine, cakebury dan sebagainya.

5. Memiliki sumberdaya manusia yang profesional, terpercaya, kompeten dan tekun

Arief Muhammad mempekerjakan karyawan yang telah berpengalaman sehingga tidak mengecewakan dalam segi pelayanan dan juga produksi.

6. Mampu mempertahankan kualitas dan rasa

Hingga saat ini Cakekinian masih ramai pengunjung dan mampu bertahan dipersaingan yang pesat karena kualitas dan rasa yang dimiliki tidak berubah dan bahkan selalu membuat rindu para konsumennya.

7. Memiliki jaringan pemasaran yang kuat dan selalu memikat target market

Cakekinian mudah dikenal dikalangan masyarakat karena memiliki "Celebrity endorse" yaitu dipromosikan melalui artis-artis ternama selain ownernya seperti: Nagita, Raffi, Irwansyah, Bella, dan sebagainya.

8. Memiliki lokasi atau tempat usaha yang strategis

Lokasi yang dipilih oleh Arief merupakan lokasi yang strategis seperti Bintaro, selain karena dekat dengan rumah dari owner tempat tersebut juga terkenal sebagai tempat nongkrong para remaja dan merupakan lokasi yang sering dijadikan perkumpulan para pebisnis. Tidak hanya di Jakarta tetapi juga terdapat dibeberapa daerah seperti: Bogor, Bekasi, Surabaya, Bandung dan lain sebagainya.

9. Memiliki harga yang terjangkau disegala kalangan terutama para pelajar Untuk produk yang dimiliki oleh seorang selebrity, Cakekinian merupakan produk yang memiliki harga terjangkau karena hanya berkisar Rp. 50.000-an

10. Memiliki kemasan yang unik dan berbeda dari yang lainnya

Kemasan yang digunakan Cakekinian tergolong unik dan bervariasi karena memiliki warna-warna yang cerah seperti warna langit dan warna muda lainnya.

11. Bahan baku yang higienis dan terjamin

Owner sebagai seorang selebrity dan influencer tentunya sangat menjamin bahan dasar yang digunakan agar tidak mengecewakan para konsumen dan tidak berdampak buruk pada yang mengkonsumsinya dengan meletakkan logo halal dikemasannya.

12. Memiliki pelayanan yang ramah dan memuaskan

Karyawan yang dimiliki Cakekinian merupakan karyawan yang profesional dan tentunya sudah terlatih sehingga karyawannya selalu memberikan pelayanan yang memuaskan karyawan dengan selalu memberikan senyuman dan sikap yang ramah terhadap pembeli.

\section{Weakness (Kelemahan)}

1. Pemberian kompensasi kepada sumber daya manusia yang dimiliki belum memenuhi standar UMR

Sebagai perusahaan yang tidak begitu besar, sehingga kompensasi yang diterima sumber daya manusia yang dimiliki masih belum memenuhi standar UMR tetapi masih bisa terbilang cukup besar daripada pelayan restoran pada umumnya.

2. Produk tidak bersifat tahan lama

Karena kue berbahan dasar dari telur, tepung dan sebagainya dan Cakekinian memiliki kue yang semacam seperti ice cream sehingga tidak dapat bertahan lama dan hanya mampu bertahan 7 hari lamanya dan tidak bisa diletakkan diluar freezer. 
3. Adanya keterbatasan karena produk hanya bisa dipasarkan pada daerah tertentu Sayangnya Cakekinian masih belum berada di seluruh daerah di Indonesia dan hanya ada dibeberapa kota saja, sehingga untuk mendapatkannya harus datang ke daerah tersebut.

4. Belum ada sistem pembelian yang dibuat secara online

Sampai saat ini Cakekinian masih belum memiliki pembelian secara online, hanya saja membuka peluang bagi yang memiliki rumah didaerah tersebut untuk menyediakan sistem "Jasa Titip".

5. Harga bahan baku yang meningkat seiring dengan perekonomian di Indonesia

Dengan perekonomian yang tidak stabil di Indonesia, tentunya menjadi kelemahan bagi pebisnis kuliner karena berdampak pada harga bahan baku yang digunakan dan juga berdampak pada harga produk yang dipasarkan.

\section{Faktor Eksternal}

\section{Opportunities (Peluang)}

1. Brand image yang dimiliki merupakan nama yang sudah dikenal dan mudah diingat Nama Cakekinian merupakan nama yang mudah diingat dan simple dengan owner yang juga sudah ternama menjadikan peluang bagi Cakekinian agar lebih mudah dikenal dikalangan masyarakat.

2. Mendukung acara-acara ternama dan mampu meningkatkan pemasaran produk

Seringkali Cakekinian berada diacara seperti bazar-bazar ternama yang ramai dikunjungi remaja maupun kalangan menengah keatas, seperti: Moslem Fest Halal Food, JakFest dan lain sebagainya agar mempermudah perkenalan konsumen dengan Cakekinian.

3. Mampu membuka lapangan pekerjaan baru

Dengan adanya usaha-usaha kue yang dibuat oleh para selebrity ini tentunya membuat bertambahnya lapangan pekerjaan, apalagi dibuka dibeberapa daerah sehingga dapat mengurangi jumlah pengangguran di Indonesia.

4. Perkembangan teknologi informasi yang semakin pesat

Sosial media yang semakin ramai digunakan dan sudah menjadi kegiatan sehari-hari masyarakan juga ikut membuka peluang Cakekinian untuk semakin dikenal oleh masyarakat, ditambah dengan owner yang selalu memasarkan dengan tanda "\#” hastag sehingga banyak orang yang melihat dan penasaran dengan produk ternama tersebut.

5. Fasilitas yang dimiliki mudah diperoleh dan sangat memadai Jika berkunjung ke outlet yang dimiliki Cakekinian dapat dilihat bahwa outlet memiliki fasilitas yang lengkap sehingga menjadikan produk Cakekinian mudah dalam melakukan inovasi.

6. Membuat inovasi pada produk agar lebih menarik minat konsumen

Owner Cakekinian selalu membuat atau menciptakan produk-produk baru yang bervariasi sehingga tidak membuat konsumen merasa jenuh, baik dalam segi rasa maupun kemasan.

\section{Threats (Ancaman)}

1. Pesaing yang terinspirasi dari Cakekinian dan membuat produk yang serupa

Timbulnya kompetitor serupa yang terinspirasi karena melihat bisnis dari Cakekinian ataupun kue artis lainnya.

2. Persepsi harga pada konsumen yang selalu menginginkan adanya diskon atau promosi Sebagai konsumen tentunya selalu menginginkan harga yang murah dengan kualitas dan rasa yang terjamin. Maka bukan hal yang tidak mungkin jika konsumen menginginkan adanya promosi atau diskon dari produk ternama yang diinginkan.

3. Adanya pertumbuhan tingkat ekonomi 
Pertumbuhan ekonomi sangat mempengaruhi harga jual karena berdampak pada harga bahan baku yang digunakan untuk pembuatan produk, sedangkan konsumen selalu menginginkan harga yang terjangkau.

Berdasarkan faktor internal dan eksternal sebagai faktor dari kunci keberhasilan pada produk Cakekinian. Berikut ini adalah analisis berdasarkan formulasi dari strategi Analisis SWOT yang diminta berdasarkan wawancara dengan beberapa karyawan yang bekerja di Cakekinian, yaitu:

\section{Penilaian Rating Strength}

\begin{tabular}{|c|l|c|c|c|}
\hline \multirow{2}{*}{ No } & \multicolumn{1}{|c|}{ Strength (Kekuatan) } & \multirow{2}{*}{ Bobot } & \multirow{2}{*}{ Rating } & \multirow{2}{*}{ Skor } \\
\cline { 2 - 4 } & \multicolumn{1}{|c|}{} & & \\
\hline 1 & Memiliki Brand yang unik & 0,11 & 2 & 0,22 \\
\hline 2 & Bisnis Cakekinian memiliki owner ternama & 0,12 & 3 & 0,36 \\
\hline 3 & Memiliki produk yang unik & 0,12 & 3 & 0,36 \\
\hline 4 & Memiliki cita rasa yang khas & 0,11 & 2 & 0,22 \\
\hline 5 & Memiliki sumberdaya manusia yang profesional & 0,11 & 2 & 0,22 \\
\hline 6 & Mampu mempertahankan kualitas dan rasa & 0,11 & 2 & 0,22 \\
\hline 7 & Memiliki jaringan pemasaran yang kuat & 0,12 & 3 & 0,36 \\
\hline 8 & Memiliki lokasi atau tempat usaha yang strategis & 0,14 & 4 & 0,56 \\
\hline 9 & Memiliki harga yang terjangkau disegala kalangan & 0,11 & 2 & 0,22 \\
\hline 10 & Memiliki kemasan yang unik dan berbeda dari yang lainnya & 0,11 & 2 & 0,22 \\
\hline 11 & Bahan baku yang higienis dan terjamin & 0,11 & 2 & 0,22 \\
\hline 12 & Memiliki pelayanan yang ramah dan memuaskan & 0,12 & 3 & 0,36 \\
\hline & & 1,39 & & 3,54 \\
\hline
\end{tabular}

Dapat dilihat bahwa hasil dari jumlah skor kekuatan yang dimiliki oleh bisnis dari Cakekinian sebesar 1,39 dengan skor 3,54.

\section{Penilaian Rating Weakness}

\begin{tabular}{|c|l|c|c|c|}
\hline \multirow{2}{*}{ No } & \multicolumn{1}{|c|}{ Weakness (Kelemahan) } & \multirow{2}{*}{ Bobot } & \multirow{2}{*}{ Rating } & \multirow{2}{*}{ Skor } \\
\cline { 2 - 4 } & \multicolumn{1}{|c|}{} & & \\
\hline 1 & Pemberian kompensasi belum memenuhi standar UMR & 0,14 & 2 & 0,28 \\
\hline 2 & Produk tidak bersifat tahan lama & 0,11 & 4 & 0,44 \\
\hline 3 & Keterbatasan produk hanya dipasarkan pada daerah tertentu & 0,11 & 3 & 0,33 \\
\hline 4 & Belum ada sistem pembelian yang dibuat secara online & 0,13 & 3 & 0,39 \\
\hline 5 & Harga bahan baku yang meningkat & 0,12 & 2 & 0,24 \\
\hline & Jumlah Skor Kelemahan & 0,61 & & 1,68 \\
\hline & Jumlah Skor Kekuatan + Kelemahan & $\mathbf{2 , 0 0}$ & & $\mathbf{5 , 2 2}$ \\
\hline
\end{tabular}

Dapat dilihat bahwa hasil dari jumlah skor kelemahan yang dimiliki oleh bisnis dari Cakekinian sebesar 0,61 dengan skor 1,68.

Jika jumlah skor kekuatan dikurangi dengan jumlah skor kelemahan.

maka: $1,39-0,61=0,78$ 


\section{Penilaian Rating Opportunities}

\begin{tabular}{|c|l|c|c|c|}
\hline \multirow{2}{*}{ No } & \multicolumn{1}{|c|}{ Opportunities (Peluang) } & \multirow{2}{*}{ Bobot } & \multirow{2}{*}{ Rating } & \multirow{2}{*}{ Skor } \\
\cline { 2 - 4 } & \multicolumn{1}{|c|}{} & & \\
\hline 1 & Brand image yang dimiliki sudah dikenal dan mudah diingat & 0,13 & 3 & 0,39 \\
\hline 2 & Mendukung acara ternama untuk meningkatkan pemasaran & 0,12 & 2 & 0,24 \\
\hline 3 & Mampu membuka lapangan pekerjaan baru & 0,11 & 3 & 0,33 \\
\hline 4 & Perkembangan teknologi informasi yang semakin pesat & 0,11 & 3 & 0,33 \\
\hline 5 & Fasilitas yang dimiliki mudah diperoleh dan sangat memadai & 0,11 & 1 & 0,11 \\
\hline 6 & Inovasi pada produk agar lebih menarik minat konsumen & 0,11 & 2 & 0,22 \\
\hline \multicolumn{2}{r}{ Jumlah Skor Peluang } & 0,69 & & 1,62 \\
\hline
\end{tabular}

Dapat dilihat bahwa hasil dari jumlah skor peluang yang dimiliki oleh bisnis dari Cakekinian sebesar 0,69 dengan skor 1,62.

\section{Penilaian Rating Threats}

\begin{tabular}{|c|l|c|c|c|}
\hline \multirow{2}{*}{ No } & \multicolumn{1}{|c|}{ Threats (Ancaman) } & \multirow{2}{*}{ Bobot } & \multirow{2}{*}{ Rating } & \multirow{2}{*}{ Skor } \\
\cline { 2 - 5 } & \multicolumn{1}{|c|}{ Faktor } & 0,10 & 4 & 0,40 \\
\hline 1 & Pesaing yang terinspirasi dari Cakekinian & 0,11 & 2 & 0,22 \\
\hline 2 & Persepsi harga pada konsumen & 0,10 & 3 & 0,30 \\
\hline 3 & Adanya pertumbuhan tingkat ekonomi & 0,31 & & 0,92 \\
\hline Jumlah Skor Peluang & $\mathbf{1 , 0 0}$ & & $\mathbf{2 , 5 4}$ \\
\hline
\end{tabular}

Dapat dilihat bahwa hasil dari jumlah skor ancaman yang dimiliki oleh bisnis dari Cakekinian sebesar 0,31 dengan skor 0,52.

Jika jumlah skor peluang dikurangi dengan jumlah skor ancaman, maka: $0,69-0,31=0,38$

Perhitungan diatas dapat dilihat bahwa adanya dua perhitungan yang dilakukan untuk menentukan posisi matriks SWOT, sebagai berikut:

1. Menjumlahkan hasil skor kekuatan dengan hasil skor kelemahan, yang berarti dari skor hasil jumlah kekuatan memiliki nilai positif sedangkan skor dari hasil kelemahan memiliki nilai yang dominan.

2. Menjumlahkan hasil skor peluang dengan hasil skor ancaman, yang berarti dari skor hasil jumlah peluang memiliki nilai positif sedangkan skor dari hasil ancaman memiliki nilai yang dominan.

Jika yang dihasilkan adalah nilai positif, maka faktor peluang lebih dominan dan begitupun sebaliknya jika nilah yang dihasilkan dominan maka berarti faktor ancaman yang lebih dinilai dominan.

\section{KESIMPULAN DAN SARAN}

Berdasarkan peneitian yang telah dilakukan dan analisa data penelitian mengenai pembahasan strategi SWOT pada bisnis Cakekinian, setelah mengetahui dan memahami apa saja kekuatan dan kelemahan serta peluang juga ancaman yang ada pada faktor internal maupun eksternal terkait kondisi produk Cakekinian sehingga dapat dilihat bahwa kekuatan yang dimiliki Cakekinian lebih besar daripada kelemahan yang ada. Hal tersebut tentunya dapat dilihat berdasaran hasil dari nilai Strength dikurangi dengan nilai Weakness, dengan demikian 
dapat menentukan langkah-langkah ataupun strategi yang diterapkan dalam jangka pendek maupun jangka panjang. Dengan adanya hasil tersebut perusahaan harus mampu untuk tetap mempertahankan kualitas. cita rasa yang khas dan juga dengan selalu memberikan pelatihan serta pengembangan sumber daya manusia agar mampu meningkatkan pelayanan yang dimiliki. Cakekinian juga dapat memanfaatkan owner ternama untuk mempromosikan produk yang dimiliki dengan menjamin segala kehigienisan dari produknya.

Dapat diketahui juga bahwa nilai Opportunitiess dikurangi dengan nilai Threat, maka menghasilkan positif yang berarti menyatakan bahwa peluang yang dimiliki Cakekinian lebih besar dibandingkan dengan nilai ancaman yang ada. Hasil tersebut maka dapat membuat atau menerapkan strategi ataupun langkah-langkan dengan mulai menggunakan sistem online agar mempermudah konsumen dalam mendapatkan produk yang diinginkan, menambah outlet untuk lebih memperbanyak lapangan pekerjaan untuk membantu mengurangi jumlah populasi pengangguran yang ada, selalu membuat inovasi-inovasi terbaru dan tetap dengan khas yang unik sebagai penanda atau ciri khas dari Cakekinian. Dengan strategi ataupun langkah-langkah yang dibuat diharapkan akan mampu mengembangkan sumber daya manusia dan membawa peningkatan secara berkelanjutan pada Cakekinian.

\section{DAFTAR RUJUKAN}

Aipama, W. (2019). Analisis SWOT Pada PT Media Pajak Indonesia (TAXMEDIA). Jurnal Ilmu Manajemen Terapan, 1 (1), 182-186.

Buchori, H. A., \& Saladin, D. (2010). Manajemen Pemasaran. Bandung: Linda Karya.

Chrismastianto, I. A. (2017). Analisis SWOT Implementasi Teknologi Finansial Terhadap Kualitas Layanan Perbankan Di Indonesia. Jurnal Ekonomi dan Bisnis, 20 (1), 131144.

Dalimunthe, L. (2019). Strategi Pengembangan Sumber Daya Manusia Guna Meningkatkan Kinerja Karyawan Melalui Analisis SWOT Divisi Cash Processing Center Pada PT Advantage SCM Kota Padang. Jurnal Ilmu Manajemen Terapan, 1 (1), 76-85.

Harahap, A. S. (2019). Analisis Strategi Peningkatan Kinerja Bagian Sekretariat Pada Dinas Pendidikan, Pemuda dan Olahraga Kota Padang. Jurnal Ilmu Manajemen Terapan, 1 (1), 69-75.

Kotler, P., \& Amstrong, G. (2013). Prinsip-Prinsip Pemasaran, Edisi ke-12. Jakarta: Erlangga.

Kotler, P., \& Keller, K. L. (2009). Manajemen Pemasaran (Jiid 1) (Edisi 3). Jakarta: Erlangga.

Kotler, P., \& Keller, K. L. (2012). Marketing Manajemen. Jakarta : Erlangga.

Sudaryono. (2016). Manajemen Pemasaran (Teori \& Implementasi). Yogyakarta: Andi.

Tjiptono, F. (2008). Strategi Pemasaran, Edisi Ketiga. Yogyakarta: Andi.

Yeni, F., Erwin, G., \& Ali, H. (2019). Analisis Strategi Pemasaran Dalam Menghadapi persaingan bisnis PadaPT. Federal Internasional Finance FIF Grup Di Kecamatan Ipuh, Kabupaten Mukomuko. Jurnal Ilmu Manajemen Terapan, 1 (1) 38-54. 
